Portland State University

PDXScholar

Jul 24th, 12:00 AM - 12:00 AM

\title{
Library Instruction West 2014: Open, Sustainable Instruction
}

Joan Petit

Portland State University

Sara Thompson

Oregon State University - Cascades Campus

Follow this and additional works at: https://pdxscholar.library.pdx.edu/liw_portland

Part of the Information Literacy Commons

Let us know how access to this document benefits you.

Petit, Joan and Thompson, Sara, "Library Instruction West 2014: Open, Sustainable Instruction" (2014). Library Instruction West 2014. 5.

https://pdxscholar.library.pdx.edu/liw_portland/Presentations/Publications/5

This Event is brought to you for free and open access. It has been accepted for inclusion in Library Instruction West 2014 by an authorized administrator of PDXScholar. Please contact us if we can make this document more accessible: pdxscholar@pdx.edu. 
In July 2014, 250 librarians from across the US, Canada, and the United Kingdom traveled to Portland, Oregon to attend Library Instruction West on the campus of Portland State University. The conference, formerly known as LOEX of the West and hosted by Portland State University Library, was a great success by all accounts. Joan Petit from PSU Library served as conference chair and as well as chair of the local arrangements committee, while Sara Thompson from Oregon State University-Cascades chaired the program committee. The conference theme, Open, Sustainable Instruction, pushed conferees in expected and unexpected ways, and more than just the conference name was new.

LOEX of the West conferences have typically had themes that relate to the city, region, or university host. The 2014 conference theme was inspired by PSU's on-going commitment to sustainability, a mission that has been integrated into several departments and disciplines on campus, as well as growing awareness of the importance of open access research. It also connects well to Portland's reputation for environmental awareness and livability. What we didn't realize was how the theme would push and inspire us as conference organizers, in small and big ways.

We acknowledge that conferences are not environmentally friendly by nature; by luring 250 librarians to downtown Portland, we contributed to pollution and energy use. However, we did attempt to mitigate this impact: as part of registration, attendees received a small recycled notebook and pen as well as a stainless steel water bottle, and we encouraged everyone to use their water bottles rather than disposable cups or bottles of water. We also tried to limit paper use: rather than printing a glossy or extensive program, we used the online software sched.org so attendees could plan their schedules in advance and use the mobile-friendly sched.org website to navigate the sessions. At the conference itself, we made available a double-sided handout with an abbreviated schedule. We encouraged our attendees to stay in low-cost on-campus housing and, for those flying into Portland, use the light rail transit system to travel from the airport to campus. These efforts were mostly successful--certainly the water bottles were a big hit--though one attendee complained that we were ageist in not printing a program. (After this complaint, we printed a full program for her from sched.org, but she declined to take it.)

The more exciting outgrowth of our theme, however, is this issue of Reference Services Review itself. As readers likely know, LOEX of the West has a long history with this journal, and articles developed from presentations at the conference have been part of a special issue many times over the years. LIW 2014 organizers were eager to continue this partnership. At the same time, inspired by including "Open" in our conference theme, Sara Thompson advocated for publishing conference proceedings and any resulting articles in an open access format. Given Portland State's burgeoning digital repository, PDXScholar, this issue resonated at PSU Library well. We approached the RSR editors with our concerns, and we are delighted to share that Emerald, the publisher of Reference Services Review, agreed that the LIW articles in this special issue could be included in post-print PDF format in PDXScholar as part of a conference collection. This is a thrilling development, and the authors extend sincere gratitude to Emerald as well as RSR editors Eleanor Mitchell and Sarah Watstein. 
While this is an exciting development, we would be remiss not to discuss another big change: the conference name. LOEX of the West, the conference, derived its name from the Michigan-based international organization LOEX, which is described as follows:

LOEX is a self-supporting, non-profit educational clearinghouse for library instruction and information literacy information. Founded in 1971 after the "First Annual Conference on Library Orientation" at Eastern Michigan University, LOEX (Library Orientation Exchange) has grown from a lending repository of library instruction materials and host of an annual conference on the subject to an internationally known organization that serves as a conduit for those working in the field.'

Inspired by the national LOEX conferences, in 1994, librarians in the Pacific Northwest organized a regional conference focused on library instruction at Willamette University in Salem, Oregon. The conference has continued every two years since then.

The 2014 organizers, however, were keenly aware of two difficulties with the conference name LOEX of the West: 1) a lack of familiarity with the national LOEX meant newer librarians were confused about the conference focus; and 2) an assumption that LOEX of the West was connected to international LOEX. Thus in 2013, conference chair Joan Petit began floating the idea of changing the name. Because LOEX of the West was always a grassroots conference, there was no board or organization to consult about this. Rather, we contacted previous conference organizers, who had no objections to a new name. We then opted to survey a larger group of stakeholders--previous attendees--about the then-current conference name as well as possible new options. The response from the survey was quite positive. Our decision was cemented when Brad Sietz, the director of LOEX, contacted Joan to share his strong support for LOEX of the West moving to a new name and distinct identity.

Joan and Sara, in consultations with librarians at Portland State, chose Library Instruction West (LIW) as the new name, which maintains both the regional and pedagogical focus of the conference. It is true that LOEX of the West and LIW are primarily academic conferences, but we felt that emphasis was not necessary to include in the conference name. By all accounts, the new name has been a great success and we anticipate that future conference organizers will continue to use it. The best part? Every mention of the conference no longer needs a qualifier explaining LOEX and the lack of affiliation between the international organization and this regional conference.

Another change for 2014 was the implementation of a conference code of conduct. The use of such codes is a relatively new trend at library conferences and is derived from the practice of some technology conferences, where many women and underrepresented minorities have faced significant harassment. In spring 2014, some librarians began to share via social media a commitment not to attend any conference without a formal code of conduct. We developed our code of conduct based on the example from the Geek Feminism

\footnotetext{
i “About LOEX”, http://www.loex.org/about.php
} 
wikii. Many attendees commented favorably on the inclusion of a conference code of conduct, which Joan read aloud during our conference-wide opening remarks and keynote. We did not receive any reports of conduct violations during the conference, and we hope that the code itself contributed to a better conference experience, including an improved feeling of safety, for our attendees.

At the heart of Library Instruction West, going back to the origins of LOEX of the West, is a sense of community. The attendees of LIW came together as colleagues and friends on numerous occasions, starting with a Wednesday evening reception in PSU Library and followed by group dinners hosted by local attendees. Strangers and old acquaintances shuffled into small groups to explore everything from the Portland Thai food scene to the annual Oregon Brew Fest on the Willamette River waterfront. The camaraderie continued Thursday when more than 200 attendees and family members gathered on a ship to enjoy a beautiful dinner cruise up the Willamette. Throughout the conference, meals were shared at the open, welcoming Native American Student and Community Center on the PSU campus.

The keynote address by Project Information Literacy Executive Director Alison J. Head set a dynamic tone for the conference toward critical reflection of our field, attention to our users, and passion for what we do. The presenters took up the reins from there and amazed us with their creativity, depth, and thoughtfulness. The diversity of sessions captured in this issue includes examples of the many exciting ideas discussed at Library Instruction West 2014. An important aspect of sustainability is finding innovative new ways to accomplish everyday jobs and that's exactly what our presenters did.

With David Brier and Vicky Lebbin, we were introduced to the idea of incorporating drawing into information literacy, which could tie in with Emily Ford's inspiring look at using digital badges in curriculum, and built upon with Kevin Seeber's exploration of teaching web-scale discovery tools in library instruction. Elizabeth Price suggested building a for-credit information literacy course around a theme to facilitate student learning, while Jody Nelson and Joan Morrison discussed their newly redesigned first year instruction program that incorporates a blended instruction model.

Speaking of tools, we discovered new approaches to old favorites thanks to Rebecca Kuglitsch experimenting with Zotero for assessment and John Oliver tinkering with Wikipedia in the name of information literacy. Rebecca Halpern and Chimene Tucker shared their strategies for developing sustainable, scalable online learning modules focused on adult learners. Keeping a level head through all this excitement, Richard Hayman and Erika Smith explored decision making strategies in choosing the best technologies for libraries and Kate Rubick shined a light on bringing Bizup's BEAM into the research process.

ii "Conference Anti-harassment/Policy", http://geekfeminism.wikia.com/wiki/Conference_anti-harassment/Policy 
Feedback from conference attendees--both via informal remarks in Portland and through the anonymous conference evaluations--was overwhelmingly positive. Here are some examples from conference evaluations:

- "The LIW Team did a great job!! Thank you very much for a fun, intellectually stimulating, and useful conference. One of the best conferences I have ever attended."

- "The organizers did a fabulous job. It really was one of the best conferences I've been to."

- $\quad$ "By most measures this was the my best library conference experience ever. The vibe was open and friendly. I was able to network with librarians in similar situations and from community colleges like mine. I was mostly able to select sessions that presented unique and useful ideas. The PSU setting was attractive and comfortable."

- "This was my first LIW and I enjoyed the experience, and I took away a lot more useful information than I have from other conferences this year."

Most significant is the impact of this conference. The feedback we received--through Twitter, blogs, and conference evaluations--tells us that LIW is changing the way librarians think about teaching and their approach to user education. We are grateful for the many presenters and attendees who contributed to the success of Library Instruction West.

Looking ahead, we are pleased to share that the University of Utah is the location for Library Instruction West 2016; librarians from the University of Utah are organizing the conference in collaboration with librarians from Westminster College and Utah State University. We hope to see you in Salt Lake City next year!

"About LOEX", available at http://www.loex.org/about.php (accessed 5 December 2014).

"Conference Anti-Harassment/Policy", available at http://geekfeminism.wikia.com/wiki/Conference anti-harassment/Policy (accessed 7 December 2014). 